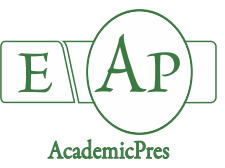

Haq S et al. (2021)

Notulae Botanicae Horti Agrobotanici Cluj-Napoca

Volume 49, Issue 2, Article number 12255

DOI: $10.15835 /$ nbha49312255

Research Article

\title{
Impact of treated sewage water on nutrient status of alfisols and vegetable crops
}

\section{Shamsul HAQ ${ }^{1}$, Ram BHAROSE ${ }^{2}$, Rouf A. BHAT ${ }^{1}$, Munir OZTURK ${ }^{3 *}$, Volkan ALTAY ${ }^{4}$, Asma A. BHATTI ${ }^{2}$, Moonisa A. DERVASH ${ }^{5}$, Khalid R. HAKEEM ${ }^{6}$}

\author{
${ }^{1}$ Sher-e-Kashmir University of Agricultural Sciences and Technology, Division of Environmental Sciences, \\ Shalimar,Kashmir,India; shamsulhaq111@gmail.com; rufi.bhat@gmail.com; ayesha.aab@gmail.com \\ ${ }^{2}$ School of Forestry and Environment, Department of Environmental Sciences, SHIA TS, Allahabad, India; \\ ram.bharose@shiats.edu.in \\ ${ }^{3}$ Ege University, Botany Department \& Centre for Environmental Studies, Izmir, Turkey; \\ munirozturk@gmail.com (*corresponding author) \\ ${ }^{4}$ Hatay Mustafa Kemal University, Department of Biology, Faculty of Science \& Arts, Hatay, Turkey; volkanaltay34@gmail.com \\ ${ }^{5}$ Sher-e-Kashmir University of Agricultural Sciences and Technology, Srinagar, Kashmir, India; \\ moonisadervash757@gmail.com \\ ${ }^{6}$ King Abdulaziz University, Faculty of Science, Department of Biological Sciences, Jeddah, Saudi Arabia; \\ kur:hakem@gmail.com
}

\begin{abstract}
This study was conducted to determine the impact on the nutrient status of soil and vegetable crops irrigated with the treated sewage water. Three samples of water and five samples of soil and five commonly grown vegetables viz. radish, carrot, spinach, cauliflower, and potato were collected from Ganjia, Arail and Dandi located in Naini, Allahabad (India). The water samples were analysed for $\mathrm{pH}$, EC, and heavy metals $\left(\mathrm{Pb}^{2+}, \mathrm{Cr}^{3+}, \mathrm{Cd}^{2+}\right.$ and $\left.\mathrm{Ni}^{2+}\right)$ concentration. Water samples from all the sites were alkaline with $\mathrm{EC}$ below the safe limits. The soil and plant samples from all the three sites showed that Gangia recorded the highest value of EC $\left(\mathrm{dS} \mathrm{m}^{-1}\right)$, organic carbon (OC) (\%), available NPK $\left(\mathrm{kg} \mathrm{ha}^{-1}\right)$, and micronutrients concentration $\left(\mathrm{Mn}^{2+}, \mathrm{Zn}^{2+}\right.$ and $\left.\mathrm{Fe}^{2+}\right)\left(\mathrm{mg} \mathrm{kg}^{-1}\right)$ whereas, the lowest concentration was recorded at Dandi followed by Arail. The soil samples collected from all three sites were alkaline. The nutrient status (N, P and K) showed the highest value in potato in the three sites, whereas manganese and zinc showed the highest value in spinach and iron in carrot. The study concludes that treated sewage water used for irrigation has a positive impact on nutrient status in soils and as well as in vegetable crops.
\end{abstract}

Keywords: alfisols; nitrogen; organic carbon; treated sewage; vegetables

\section{Introduction}

Approximately 20 million ha in 50 countries are irrigated with wastewater (Verma et al., 2015; Khalid et al., 2017). The wastewater is frequently used for crop irrigation, without any prior treatment in peri-urban 
areas of many countries in Asia (Murtaza et al., 2010; Farid et al., 2014; Khan et al., 2015; Qureshi et al., 2016; Khalid et al., 2017).

Nearly 80 percent of the water used for household purposes and in the industry is discharged back as wastewater in many countries. According to the report published in 2007, the total urban wastewater generated in India alone is around 38.000 million liters per day (MLD), and overexploitation of groundwater use is increasing (Verma et al., 2015). The class-I, class-II cities, and towns represent 72 percent of the urban population in India. These areas produce nearly 98 liters per capita per day (LPCD) of wastewater. On the other hand, the capital city Delhi alone discharges 3.663 MLD of wastewater, which is over 220 LPCD, but approximately 61 percent of this is treated (CPCB, 2007). The sewage generation in Varanasi is 230.17 MLD, and only 44 percent is treated $(\mathrm{CPCB}, 2007)$. CPCB estimates are that total wastewater generation from Class I cities (498) and Class II (410) towns in the country is around 35.558 and 2.696 MLD respectively; but, the installed sewage treatment capacity for these is just 11.553 and $233 \mathrm{MLD}$. This leads to a gap of 26.468 MLD in sewage treatment capacity (CPCB, 2007).

In India, the major contributions to the wastewater in Delhi and several other States (63\%; CPCB, 2007). The projections given for 2050 are that nearly 132 billion liters per day of wastewater will be generated, this amount has the potential to meet about 5 percent of the total irrigation water demand (Kaur et al., 2012). The future analysis of water resources indicates that due to population overload and industrialization the public will face a twin-edged problem with reduced freshwater availability and increased wastewater generation (Kaur et al., 2012).

The waters of marginal quality like sewage and others are used to supplement irrigation needs in many countries where good quality of water is limited (Ozturk et al., 2005, 2011; Sharma et al., 2012; Maya et al., 2016). Nitrogen, phosphorus, and potassium content of sewage generally range from 1 to $1.5 \%, 1$ to $12 \%$, and 0.35 to $0.8 \%$, respectively.

The sewage water evaluation in agriculture is an age-old practice (Mani et al., 2013). The use of wastewater for crop irrigation has certain advantages, such as the supply of essential plant nutrients and organic matter to the soil, saving water, and nutrients and reducing water pollution (Murtaza et al., 2010; Mani et al., 2013; Akınbile et al., 2016; Khalid et al., 2017). Moreover, irrigation with sewage water increases soil electrical conductivity and organic carbon, contributes to the supply of macro and micronutrients for plant growth, regulates soil buffer capacity, as well as soil cation exchange capacity (CEC), but at the same time decreases soil $\mathrm{pH}$. However, it can also result in the accumulation of heavy metals in the plow layer of agricultural soils when applied for a long term with indiscriminate use and without pre-control that may prove hazardous to human health (Ghosh et al., 2012; Amin et al., 2012). Despite this, the use of sewage effluents for irrigating agricultural lands is increasing in many industrializing countries due to a lack of enough fresh water supplies (Verma et al., 2015).

During the last few decades, numerous studies have focused on the cultivation of vegetables on wastewater-irrigated soils and the associated health risks (Pourrut et al., 2011; Mahmood and Malik, 2014; Xiong et al., 2016; Zia et al., 2016). It is reported that vegetables may accumulate metals in concentrations greater than the maximum permissible limits with serious public health implications (Shaheen et al., 2016). Keeping this in view, it is highly practical to monitor and reduce health risks associated with the cultivation of vegetables on contaminated soils (Khalid et al., 2017). Because of the increasing vulnerability related to the consumption of vegetables with heavy metal accumulation, it is of practical significance to determine the heavy metal accumulations in the soil as well as the vegetables irrigated with wastewater (Chang et al., 2013; Verma et al., 2015), the current study was therefore planned with this aim. 


\section{Materials and Methods}

\section{Studyarea}

The experimental work was done on the selected sites in Naini, Allahabad (India), where farmers usually irrigate their fields with sewage water. The climate of the study area is sub-tropical with summer temperatures reaching up to $48^{\circ} \mathrm{C}$, whereas the winter temperatures may be as low as $1.8^{\circ} \mathrm{C}$, with occasional frost in winter and extreme dry hot strong wind (loo) in summer. The average annual rainfall of the study area is about $50 \mathrm{~cm}$.

A survey of the area using treated sewage water for irrigation was carried out at selected locations. Several vegetables like radish, carrot, spinach, cauliflower, and potato are grown extensively on these soils therefore these species were chosen for analytical evaluation. Three sampling sites namely Ganjia, Arail, and Dandi were selected keeping in view the increase in distance from the disposal site.

\section{Data analyses}

Three samples of sewage water used for irrigation of vegetables were collected and analyzed for $\mathrm{pH}$, electrical conductivity (EC), and heavy metals $\left(\mathrm{Pb}^{2+}, \mathrm{Cd}^{2+}, \mathrm{Cr}^{3+}\right.$, and $\left.\mathrm{Ni}^{2+}\right) . \mathrm{EC}$ and $\mathrm{pH}$ of water were determined according to APHA (1998). Heavy metals $\left(\mathrm{Pb}^{2+}, \mathrm{Cd}^{2+}, \mathrm{Cr}^{3+}\right.$, and $\left.\mathrm{Ni}^{2+}\right)$ concentrations were determined by atomic absorption spectrophotometer (Perveen et al., 2012). Soil samples at the depths (0-15 and $15-30 \mathrm{~cm}$ ) were collected from each site, bypassed through a $2 \mathrm{~mm}$ sieve and analyzed for $\mathrm{pH}$, electrical conductivity (1:2.5 soil water suspension), organic carbon, available nitrogen (alkaline permanganate method), available phosphorus (calorimetric method), available potassium (flame photometric method) and available micronutrients $\left(\mathrm{Fe}^{2+}, \mathrm{Mn}^{2+}, \mathrm{Zn}^{2+}\right.$ and $\left.\mathrm{Cu}^{2+}\right)$ in DTPA extraction atomic absorption spectrophotometer as adopted by Kiran et al. (2012).

The plant samples (radish, carrot, spinach, cauliflower, and potato) were also collected from the fields irrigated with the sewage water. These were washed with the tap water followed by acidified water, distilled water, and double-distilled water (Lone et al., 2013). Plant samples were digested and analyzed for nitrogen (modified macro-Kjeldahl method), phosphorus (vanadomolibdate method), potassium (flame photometry), and micronutrients like $\mathrm{Fe}^{2+}, \mathrm{Mn}^{2+}$ and $\mathrm{Zn}^{2+}$ were determined by (Di-acid Digestion $\left(\mathrm{HNO}_{3}: \mathrm{HC}_{1} \mathrm{O}_{4}, 3: 1\right.$ ) method described by Rapheal and Adebayo (2011).

\section{Results}

The sewage water of the three sites viz. Gangia, Arail, and Dandi were slightly alkaline with mean $\mathrm{pH}$ ranging between 7.24 to 7.81 , and the highest $\mathrm{pH}$ value (7.90) was observed at Dandi. The irrigation water of these sites had EC values ranging from 0.91 to $1.18 \mathrm{dS} \mathrm{m}{ }^{-1}$. Among the heavy metals, $\mathrm{Pb}^{2+}$ was the highest (1.04$2.16 \mathrm{mg} / \mathrm{L})$ followed by $\mathrm{Cr}^{3+}(0.94-1.94 \mathrm{mg} / \mathrm{L}), \mathrm{Ni}^{2+}(0.10-1.34 \mathrm{mg} / \mathrm{L})$ and lowest was $\mathrm{Cd}^{2+}(0.01-0.07 \mathrm{mg} / \mathrm{L})$ at all the three sites (Table 1). The levels of heavy metal contamination in the water samples showed marked variation. Water samples from Gangia showed the highest level of $\mathrm{Pb}^{2+}(2.16 \mathrm{mg} / \mathrm{L}), \mathrm{Cr}^{3+}(1.94 \mathrm{mg} / \mathrm{L})$ and $\mathrm{Cd}^{2+}(0.05 \mathrm{mg} / \mathrm{L})$. Samples from Arail had the highest levels of $\mathrm{Ni}^{2+}(1.28 \mathrm{mg} / \mathrm{L})$, whereas the lowest level of $\mathrm{Cd}^{2+}(0.01 \mathrm{mg} / \mathrm{L})$ was observed at Dandi.

Comparing our data with the findings reported by several authors from other countries in Asia, we observed that relatively high values of $\mathrm{Pb}^{2+}$ were observed (Chandra et al., 2009; Kashif et al., 2009; Sing et al., 2010; Khan et al., 2013; Mahmood and Malik, 2014; Randhawa et al., 2014; Iqbal et al., 2015; Khanum et al., 2017). On the other hand, the values of Cd were lower than those given by Tiwari et al. (2011), Akhtar et al. (2014), and Wantong et al. (2014). The concentration of $\mathrm{Pb}^{2+}(1.08-2.10 \mathrm{mg} / \mathrm{L})$ was very high in our studies, above the maximum permissible limit set by WWF (2007) (the max. permissible limit for $\mathrm{Pb}^{2+}$ in irrigation water is $0.1 \mathrm{mg} / \mathrm{L})$. Relatively higher values of $\mathrm{Cr}^{3+}$ have been recorded here as compared to the values given by Chandra et al. (2009), Kashif et al. (2009), Sing et al. (2010), Khan et al. (2013), Mahmood and Malik (2014), 
Randhawa et al. (2014), Wantong et al. (2014), Iqbal et al. (2015), and Khanum et al. (2017). However, the values of $\mathrm{Cr}^{3+}$ were lower than those given by Tiwari et al. (2011). The concentration of $\mathrm{Cr}^{3+}(1.00-1.86 \mathrm{mg} / \mathrm{L})$ was very high in our samples, above the maximum permissible limit set by FAO/WHO (2011) (the max. permissible limit for $\mathrm{Cr}^{3+}$ in irrigation water is $\left.0.1 \mathrm{mg} / \mathrm{L}\right)$. The concentration of $\mathrm{Ni}^{2+}(0.64-1.29 \mathrm{mg} / \mathrm{L})$ too was very high above the maximum permissible limit set by WWF (2007) (the max. permissible limit for $\mathrm{Ni}^{2+}$ in irrigation water is $0.20 \mathrm{mg} / \mathrm{L}$ ).

Table 1. Chemical characteristics of the sewage water from different sites

\begin{tabular}{|c|c|c|c|c|c|}
\hline Sites & Parameters & Sample-I & Sample-II & Sample-III & Mean \\
\hline \multirow{6}{*}{ 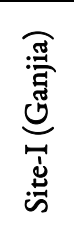 } & $\mathrm{pH}$ & 7.20 & 7.50 & 7.02 & 7.24 \\
\hline & $\mathrm{EC} \mathrm{dS} \mathrm{m}{ }^{-1}$ & 1.30 & 1.21 & 1.03 & 1.18 \\
\hline & $\mathrm{Pb}(\mathrm{mg} / \mathrm{L})$ & 2.06 & 2.16 & 2.10 & 2.10 \\
\hline & $\mathrm{Cd}(\mathrm{mg} / \mathrm{L})$ & 0.05 & 0.05 & 0.07 & 0.06 \\
\hline & $\mathrm{Ni}(\mathrm{mg} / \mathrm{L})$ & 1.25 & 1.25 & 1.34 & 1.29 \\
\hline & $\mathrm{Cr}(\mathrm{mg} / \mathrm{L})$ & 1.94 & 1.86 & 1.79 & 1.86 \\
\hline \multirow{6}{*}{ 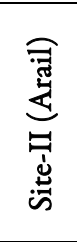 } & $\mathrm{pH}$ & 7.60 & 7.82 & 7.58 & 7.56 \\
\hline & $\mathrm{EC} \mathrm{dS} \mathrm{m^{-1 }}$ & 0.97 & 1.20 & 1.05 & 1.07 \\
\hline & $\mathrm{Pb}(\mathrm{mg} / \mathrm{L})$ & 1.96 & 1.89 & 1.86 & 1.90 \\
\hline & $\mathrm{Cd}(\mathrm{mg} / \mathrm{L})$ & 0.05 & 0.03 & 0.04 & 0.04 \\
\hline & $\mathrm{Ni}(\mathrm{mg} / \mathrm{L})$ & 1.28 & 1.04 & 1.09 & 1.13 \\
\hline & $\mathrm{Cr}(\mathrm{mg} / \mathrm{L})$ & 1.82 & 1.67 & 1.54 & 1.67 \\
\hline \multirow{6}{*}{ 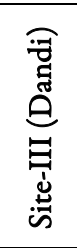 } & $\mathrm{pH}$ & 7.79 & 7.85 & 7.90 & 7.81 \\
\hline & $\mathrm{EC} \mathrm{dS} \mathrm{m^{-1 }}$ & 1.01 & 0.92 & 0.82 & 0.91 \\
\hline & $\mathrm{Pb}(\mathrm{mg} / \mathrm{L})$ & 1.04 & 1.09 & 1.11 & 1.08 \\
\hline & $\mathrm{Cd}(\mathrm{mg} / \mathrm{L})$ & 0.04 & 0.01 & 0.02 & 0.02 \\
\hline & $\mathrm{Ni}(\mathrm{mg} / \mathrm{L})$ & 0.98 & 0.86 & 0.10 & 0.64 \\
\hline & $\mathrm{Cr}(\mathrm{mg} / \mathrm{L})$ & 1.12 & 0.96 & 0.94 & 1.00 \\
\hline
\end{tabular}

The values of $\mathrm{Cd}^{2+}$ were relatively lower than the values published by several authors from other Asian countries (Chandra et al., 2009; Kashif et al., 2009; Tiwari et al., 2011; Khan et al., 2013; Akhtar et al., 2014; Mahmood and Malik, 2014; Randhawa et al., 2014; Iqbal et al., 2015; Khanum et al., 2017). However, the value of $\mathrm{Cd}^{2+}$ in our investigation was higher than those given by Sing et al. (2010). The $\mathrm{Cd}^{2+}$ concentration in the sewage water recorded by Wantong et al. (2014) was in agreement with our results. In general, the concentrations of $\mathrm{Cd}^{2+}(0.02-0.06 \mathrm{mg} / \mathrm{L})$ in our samples were slightly above the maximum permissible limit set by WWF (2007) (the max. permissible limit for $\mathrm{Cd}^{2+}$ in irrigation water is $0.01 \mathrm{mg} / \mathrm{L}$ ).

The sewage waters used in this study have shown the trends of heavy metals as; $\mathrm{Pb}^{2+}>\mathrm{Cr}^{3+}>\mathrm{Ni}^{2+}>\mathrm{Cd}^{2+}$. The differences in the levels of heavy metals in water can be associated with the use of different quantity and quality of sewage and sludge, level and type of industrial plant near the sampling area, the proximity of field from the source, presence of thermal power plants, and use of different types of agrochemicals containing heavy metals (Singh and Kumar, 2006; Perveen et al., 2012).

The mean $\mathrm{pH}$ value recorded at $0-15$ and $15-30 \mathrm{~cm}$ depth at all the sites was alkaline with the highest $\mathrm{pH}$ observed at Dandi (7.84 and 7.34) followed by Arail (7.46 and 7.09) whereas, the lowest $\mathrm{pH}$ was recorded at Gangia (7.36 and 7.08), as shown in Table 2. The maximum EC at 0-15 and $15-30 \mathrm{~cm}$ depth $\left(\mathrm{dS} \mathrm{m} \mathrm{m}^{-1}\right)$ was recorded at Ganjia (0.34 and 0.30) and the minimum was observed at Dandi ( 0.28 and 0.24$)$ followed by Arail $(0.33$ and 0.30$)$ as shown in Table 3. The mean percentage (\%) of organic carbon was observed to be significantly greater in Gangia (1.90 and 1.59\%), but the lowest was observed at Dandi (0.74 and 0.55) (Table 4). This may be attributed to the fact that Gangia probably received sewage water for irrigation for a long time and is also located nearer to the sewage discharge point compared to Arail and Dandi. The mean organic carbon was found to decrease abruptly with the increase in soil depth, which can be due to anaerobic reactions in the soil with increasing soil depth. Similar findings have also been reported by Singh and Verloo (1996), and 
Saraswat et al. (2005). Morugan-Coronado et al. (2011) have found that electrical conductivity and sodium content of soil increase but no remarkable change in soil organic carbon and microbial biomass carbon is observed due to the low organic carbon content of the water used for irrigation in the Mediterranean countries. On the contrary, Xue et al. (2012) have reported that there was an increase in the values of organic matter in the soil irrigated with sewage water compared to the soil irrigated with fresh water.

Table 2. Depth wise $\mathrm{pH}$ of soil water suspension 1:2.5 (w/v) in the soils from different sites

\begin{tabular}{|c|c|c|c|c|c|c|c|c|c|c|c|c|c|}
\hline \multirow{2}{*}{\multicolumn{2}{|c|}{\begin{tabular}{|l|} 
Soil samples \\
\end{tabular}}} & \multicolumn{6}{|c|}{$0-15 \mathrm{~cm}$} & \multicolumn{6}{|c|}{$15-30 \mathrm{~cm}$} \\
\hline & & $S_{1}$ & $\mathrm{~S}_{2}$ & $\mathrm{~S}_{3}$ & $S_{4}$ & $\mathrm{~S}_{5}$ & Mean & $\mathrm{S}_{1}$ & $\mathrm{~S}_{2}$ & $\mathrm{~S}_{3}$ & $\mathrm{~S}_{4}$ & $\mathrm{~S}_{5}$ & Mean \\
\hline \multicolumn{2}{|c|}{ Site-I (Ganjia) } & 7.32 & 7.38 & 7.40 & 7.39 & 7.31 & 7.36 & 7.16 & 7.05 & 7.12 & 7.04 & 7.04 & 7.08 \\
\hline \multicolumn{2}{|c|}{ Site-II (Arail) } & 7.37 & 7.54 & 7.38 & 7.51 & 7.48 & 7.46 & 7.02 & 7.13 & 7.10 & 7.08 & 7.12 & 7.09 \\
\hline \multicolumn{2}{|c|}{ Site-III (Dandi) } & 7.80 & 7.74 & 7.85 & 7.91 & 7.89 & 7.84 & 7.20 & 7.30 & 7.15 & 7.61 & 7.43 & 7.34 \\
\hline \multicolumn{2}{|c|}{ Mean } & 7.50 & 7.55 & 7.54 & 7.60 & 7.56 & & 7.13 & 7.16 & 7.12 & 7.24 & 7.20 & \\
\hline \multirow{2}{*}{$p<0.05$} & $\begin{array}{c}\text { Soil } \\
\text { samples }\end{array}$ & \multicolumn{6}{|c|}{ NS } & \multicolumn{6}{|c|}{ NS } \\
\hline & Sites & \multicolumn{6}{|c|}{0.08} & \multicolumn{6}{|c|}{0.17} \\
\hline
\end{tabular}

Table 3. Depth wise electrical conductivity $\left(\mathrm{dS} \mathrm{m} \mathrm{m}^{-1}\right)$ of soil water suspension 1:2.5 (w/v) in the soils from different sites

\begin{tabular}{|c|c|c|c|c|c|c|c|c|c|c|c|c|c|}
\hline \multirow{2}{*}{\multicolumn{2}{|c|}{ Soil samples }} & \multicolumn{6}{|c|}{$0-15 \mathrm{~cm}$} & \multicolumn{6}{|c|}{$15-30 \mathrm{~cm}$} \\
\hline & & $S_{1}$ & $\mathrm{~S}_{2}$ & $\mathrm{~S}_{3}$ & $\mathrm{~S}_{4}$ & $\mathrm{~S}_{5}$ & Mean & $S_{1}$ & $\mathrm{~S}_{2}$ & $\mathrm{~S}_{3}$ & $\mathrm{~S}_{4}$ & $\mathrm{~S}_{5}$ & Mean \\
\hline \multicolumn{2}{|c|}{ Site-I (Ganjia) } & 0.35 & 0.34 & 0.35 & 0.34 & 0.33 & 0.34 & 0.30 & 0.31 & 0.30 & 0.31 & 0.30 & 0.30 \\
\hline \multicolumn{2}{|c|}{ Site-II (Arail) } & 0.34 & 0.33 & 0.32 & 0.33 & 0.33 & 0.33 & 0.31 & 0.30 & 0.29 & 0.30 & 0.32 & 0.30 \\
\hline \multicolumn{2}{|c|}{ Site-III (Dandi) } & 0.28 & 0.27 & 0.28 & 0.27 & 0.28 & 0.28 & 0.21 & 0.26 & 0.26 & 0.23 & 0.24 & 0.24 \\
\hline \multicolumn{2}{|c|}{ Mean } & 0.32 & 0.32 & 0.32 & 0.32 & 0.31 & & 0.27 & 0.29 & 0.29 & 0.28 & 0.28 & \\
\hline \multirow[t]{2}{*}{$p<0.05$} & $\begin{array}{c}\text { Soil } \\
\text { samples }\end{array}$ & \multicolumn{6}{|c|}{ NS } & \multicolumn{6}{|c|}{ NS } \\
\hline & Sites & \multicolumn{6}{|c|}{0.01} & \multicolumn{6}{|c|}{1.128} \\
\hline
\end{tabular}

Table 4. Depth wise percent organic carbon in the soils from different sites

\begin{tabular}{|c|c|c|c|c|c|c|c|c|c|c|c|c|c|}
\hline \multirow{2}{*}{\multicolumn{2}{|c|}{\begin{tabular}{|l|} 
Soil samples \\
\end{tabular}}} & \multicolumn{6}{|c|}{$0-15 \mathrm{~cm}$} & \multicolumn{6}{|c|}{$15-30 \mathrm{~cm}$} \\
\hline & & $S_{1}$ & $\mathrm{~S}_{2}$ & $\mathrm{~S}_{3}$ & $S_{4}$ & $\mathrm{~S}_{5}$ & Mean & $S_{1}$ & $\mathrm{~S}_{2}$ & $\mathrm{~S}_{3}$ & $S_{4}$ & $\mathrm{~S}_{5}$ & Mean \\
\hline \multicolumn{2}{|c|}{ Site-I (Ganjia) } & 1.92 & 1.87 & 1.89 & 1.95 & 1.89 & 1.90 & 1.73 & 1.44 & 1.48 & 1.64 & 1.68 & 1.59 \\
\hline \multicolumn{2}{|c|}{ Site-II (Arail) } & 0.89 & 0.93 & 0.99 & 0.89 & 0.90 & 0.92 & 0.74 & 0.67 & 0.78 & 0.69 & 0.71 & 0.71 \\
\hline \multicolumn{2}{|c|}{ Site-III (Dandi) } & 0.77 & 0.74 & 0.78 & 0.75 & 0.69 & 0.74 & 0.58 & 0.61 & 0.54 & 0.53 & 0.51 & 0.55 \\
\hline \multicolumn{2}{|c|}{ Mean } & 1.19 & 1.18 & 1.22 & 1.19 & 1.16 & & 1.01 & 0.90 & 0.93 & 0.95 & 0.96 & \\
\hline \multirow{2}{*}{$p<0.05$} & $\begin{array}{c}\text { Soil } \\
\text { samples }\end{array}$ & \multicolumn{6}{|c|}{ NS } & \multicolumn{6}{|c|}{ NS } \\
\hline & Sites & \multicolumn{6}{|c|}{0.05} & \multicolumn{6}{|c|}{0.112} \\
\hline
\end{tabular}

The maximum N, P, and $\mathrm{K}$ of sewage irrigated soils at $0-15$ and $15-30 \mathrm{~cm}$ was observed at Ganjia followed by Arail whereas the minimum value was observed at Dandi (Tables 5-7). The mean N, P, and K kg $\mathrm{ha}^{-1}$ of sewage irrigated soils were found to decrease abruptly with the increase in soil depth. This fact can be associated with the presence of Gangia closer to the discharge point with high concentrations of nitrogen, phosphorus, and potassium; therefore, it brings a significant increase in the available N, P, and K of soils as well. Similar findings have been reported by Mitra and Gupta (1999), Yadav et al. (2002), Malla and Totawat (2006), Rojas-Valencia et al. (2011), and Xue et al. (2012). 
Table 5. Available nitrogen $\left(\mathrm{kg} \mathrm{ha}^{-1}\right)$ in soils of different sites at different depths $(\mathrm{cm})$

\begin{tabular}{|c|c|c|c|c|c|c|c|c|c|c|c|c|c|}
\hline \multirow{2}{*}{\multicolumn{2}{|c|}{ Soil samples }} & \multicolumn{6}{|c|}{$0-15 \mathrm{~cm}$} & \multicolumn{6}{|c|}{$15-30 \mathrm{~cm}$} \\
\hline & & $S_{1}$ & $\mathrm{~S}_{2}$ & $\mathrm{~S}_{3}$ & $\mathrm{~S}_{4}$ & $\mathrm{~S}_{5}$ & Mean & $S_{1}$ & $\mathrm{~S}_{2}$ & $\mathrm{~S}_{3}$ & $\mathrm{~S}_{4}$ & $\mathrm{~S}_{5}$ & Mean \\
\hline \multicolumn{2}{|c|}{ Site-T (Ganjia) } & 360.00 & 350.30 & 328.60 & 338.30 & 320.00 & 339.40 & 352.60 & 348.60 & 320.00 & 330.60 & 311.60 & 332.70 \\
\hline \multicolumn{2}{|c|}{ Site-II (Arail) } & 305.00 & 280.00 & 276.66 & 275.00 & 278.33 & 283.00 & 296.60 & 273.33 & 272.30 & 270.00 & 272.30 & 276.90 \\
\hline \multicolumn{2}{|c|}{ Site-III (Dandi) } & 259.60 & 252.40 & 260.30 & 251.56 & 249.50 & 254.60 & 250.40 & 248.00 & 256.00 & 250.00 & 242.30 & 249.30 \\
\hline \multicolumn{2}{|c|}{ Mean } & 308.20 & 294.20 & 288.50 & 288.30 & 282.60 & & 299.10 & 290.00 & 282.70 & 283.50 & 275.40 & \\
\hline \multirow[t]{2}{*}{$p<0.05$} & $\begin{array}{c}\text { Soil } \\
\text { samples }\end{array}$ & \multicolumn{6}{|c|}{ NS } & \multicolumn{6}{|c|}{ NS } \\
\hline & Sites & \multicolumn{6}{|c|}{11.47} & \multicolumn{6}{|c|}{13.45} \\
\hline
\end{tabular}

Table 6. Available phosphorus $\left(\mathrm{kg} \mathrm{ha}^{-1}\right)$ in soils of different sites at different depths $(\mathrm{cm})$

\begin{tabular}{|c|c|c|c|c|c|c|c|c|c|c|c|c|c|}
\hline \multirow{2}{*}{\multicolumn{2}{|c|}{\begin{tabular}{|l|} 
Soil samples \\
\end{tabular}}} & \multicolumn{6}{|c|}{$0-15 \mathrm{~cm}$} & \multicolumn{6}{|c|}{$15-30 \mathrm{~cm}$} \\
\hline & & $S_{1}$ & $\mathrm{~S}_{2}$ & $S_{3}$ & $S_{4}$ & $\mathrm{~S}_{5}$ & Mean & $S_{1}$ & $\mathrm{~S}_{2}$ & $S_{3}$ & $S_{4}$ & S5 & Mean \\
\hline \multicolumn{2}{|c|}{ Site-I (Ganjia) } & 36.50 & 34.03 & 32.61 & 31.62 & 32.00 & 33.35 & 35.10 & 32.43 & 31.03 & 30.60 & 30.40 & 31.91 \\
\hline \multicolumn{2}{|c|}{ Site-II (Arail) } & 28.92 & 29.03 & 30.10 & 27.80 & 28.15 & 28.80 & 27.03 & 26.13 & 29.10 & 24.63 & 27.14 & 26.81 \\
\hline \multicolumn{2}{|c|}{ Site-III (Dandi) } & 23.56 & 24.83 & 25.47 & 24.03 & 24.11 & 24.40 & 22.51 & 22.61 & 23.10 & 22.43 & 22.23 & 22.58 \\
\hline \multicolumn{2}{|l|}{ Mean } & 29.66 & 29.30 & 29.39 & 27.82 & 28.09 & & 28.21 & 27.06 & 27.74 & 25.89 & 26.59 & \\
\hline \multirow[t]{2}{*}{$p<0.05$} & $\begin{array}{c}\text { Soil } \\
\text { samples }\end{array}$ & \multicolumn{6}{|c|}{ NS } & \multicolumn{6}{|c|}{ NS } \\
\hline & Sites & \multicolumn{6}{|c|}{1.66} & \multicolumn{6}{|c|}{1.86} \\
\hline
\end{tabular}

Table 7. Available potassium $\left(\mathrm{kg} \mathrm{ha}^{-1}\right)$ in soils of different sites at different depths $(\mathrm{cm})$

\begin{tabular}{|c|c|c|c|c|c|c|c|c|c|c|c|c|c|}
\hline \multirow{2}{*}{\multicolumn{2}{|c|}{ Soil samples }} & \multicolumn{6}{|c|}{$0-15 \mathrm{~cm}$} & \multicolumn{6}{|c|}{$15-30 \mathrm{~cm}$} \\
\hline & & $S_{1}$ & $S_{2}$ & $\mathrm{~S}_{3}$ & $\mathrm{~S}_{4}$ & $S_{5}$ & Mean & $S_{1}$ & $\mathrm{~S}_{2}$ & $\mathrm{~S}_{3}$ & $\mathrm{~S}_{4}$ & $\mathrm{~S}_{5}$ & Mean \\
\hline \multicolumn{2}{|c|}{ Site-I (Ganjia) } & 269.00 & 258.66 & 249.00 & 251.33 & 248.63 & 255.32 & 266.66 & 254.66 & 243.00 & 232.66 & 236.03 & 246.60 \\
\hline \multicolumn{2}{|c|}{ Site-II (Arail) } & 241.43 & 239.33 & 242.61 & 238.13 & 239.40 & 240.18 & 238.11 & 229.43 & 230.13 & 228.03 & 229.56 & 231.05 \\
\hline \multicolumn{2}{|c|}{ Site-III (Dandi) } & 220.10 & 219.56 & 215.43 & 219.96 & 212.63 & 217.54 & 214.61 & 210.63 & 209.96 & 212.90 & 210.03 & 211.63 \\
\hline \multicolumn{2}{|c|}{ Mean } & 243.51 & 239.18 & 235.68 & 236.47 & 233.55 & & 239.79 & 231.57 & 227.70 & 224.53 & 225.21 & \\
\hline \multirow[t]{2}{*}{$p<0.05$} & $\begin{array}{c}\text { Soil } \\
\text { samples }\end{array}$ & \multicolumn{6}{|c|}{ NS } & \multicolumn{6}{|c|}{ NS } \\
\hline & Sites & \multicolumn{6}{|c|}{6.24} & \multicolumn{6}{|c|}{9.26} \\
\hline
\end{tabular}

The maximum concentration of micronutrients i.e., $\mathrm{Mn}^{2+}, \mathrm{Zn}^{2+}$, and $\mathrm{Fe}^{2+}\left(\mathrm{mg} \mathrm{kg}^{-1}\right)$ of sewage water irrigated soils at 0-15 and 15-30 was recorded in Ganjia whereas, minimum content was observed at Dandi as shown in Tables 8, 9 and 10. Mean value of $\mathrm{Mn}^{2+}, \mathrm{Zn}^{2+}$ and $\mathrm{Fe}^{2+}\left(\mathrm{mg} \mathrm{kg}^{-1}\right)$ recorded at Ganjia at $0-15 \mathrm{~cm}$ and $15-30 \mathrm{~cm}$ depth was found to be 31.97 and $30.79 \mathrm{mg} \mathrm{kg}^{-1}, 114.47$ and $111.96 \mathrm{mg} \mathrm{kg}^{-1}$ and 96.93 and $96.49 \mathrm{mg}$ $\mathrm{kg}^{-1}$, whereas, $\mathrm{Mn}^{2+}, \mathrm{Zn}^{2+}$ and $\mathrm{Fe}^{2+}\left(\mathrm{mg} \mathrm{kg}^{-1}\right)$ recorded at Arail at 0-15 and 15-30 $\mathrm{cm}$ depth was 26.24 and 25.83 $\mathrm{mg} \mathrm{kg}^{-1}, 96.72$ and $96.01 \mathrm{mg} \mathrm{kg}^{-1}$ and 85.78 and $85.13 \mathrm{mg} \mathrm{kg}^{-1}$. The minimum concentration of $\mathrm{Mn}^{2+}, \mathrm{Zn}^{2+}$, and $\mathrm{Fe}^{2+}\left(\mathrm{mg} \mathrm{kg}^{-1}\right)$ recorded at Dandi at 0-15 and 15-30 $\mathrm{cm}$ depth was 22.67 and $21.74 \mathrm{mg} \mathrm{kg}^{-1}, 93.47$ and $93.02 \mathrm{mg}$ $\mathrm{kg}^{-1}$ and 79.06 and $77.60 \mathrm{mg} \mathrm{kg}^{-1}$, respectively. The maximum concentration of $\mathrm{Mn}^{2+}, \mathrm{Zn}^{2+}$ and Fe${ }^{2+}$ in soils of Ganjia may be due to the continuous use of sewage water for irrigation purposes during the long periods and also due to its near location to the sewage discharge point. The sewage water contains an appreciably high amount of $\mathrm{Mn}^{2+}, \mathrm{Zn}^{2+}$, and $\mathrm{Fe}^{2+}$ and gradually decreases with the increase with distance from the discharge point. These findings are in accordance with the findings reported by Singh and Singh (1994), and Saraswat et al. (2005). 
Table 8. Manganese $\left(\mathrm{mg} \mathrm{kg}^{-1}\right)$ in soils different sites at different depths $(\mathrm{cm})$

\begin{tabular}{|c|c|c|c|c|c|c|c|c|c|c|c|c|c|}
\hline & & & $0-15 c$ & & & & & & & 15 & $30 \mathrm{~cm}$ & & \\
\hline Soil sampl & & $S_{1}$ & $S_{2}$ & $\mathrm{~S}_{3}$ & $S_{4}$ & $S_{5}$ & Mean & $S_{1}$ & $S_{2}$ & $S_{3}$ & $S_{4}$ & $S_{5}$ & Mean \\
\hline Site-I (Gar & & 31.96 & 30.56 & 33.66 & 31.76 & 31.90 & 31.97 & 30.50 & 29.66 & 33.10 & 30.23 & 30.46 & 30.79 \\
\hline Site-II (Ar & & 29.13 & 27.66 & 26.06 & 25.30 & 23.06 & 26.24 & 28.56 & 27.30 & 25.70 & 24.83 & 22.76 & 25.83 \\
\hline Site-III (D & & 24.60 & 23.46 & 22.53 & 21.83 & 20.93 & 22.67 & 23.00 & 22.73 & 21.93 & 21.20 & 19.86 & 21.74 \\
\hline Mean & & 28.56 & 27.23 & 27.42 & 26.30 & 25.30 & & 27.35 & 26.56 & 26.91 & 25.42 & 24.36 & \\
\hline$p<0.05$ & $\begin{array}{c}\text { Soil } \\
\text { samples }\end{array}$ & & & & & & & & & & NS & & \\
\hline & Sites & & & & & & & & & & .84 & & \\
\hline
\end{tabular}

Table 9. Zinc $\left(\mathrm{mg} \mathrm{kg}^{-1}\right)$ in soils different sites at different depths $(\mathrm{cm})$

\begin{tabular}{|c|c|c|c|c|c|c|c|c|c|c|c|c|c|}
\hline \multicolumn{8}{|c|}{$0-15 \mathrm{~cm}$} & \multicolumn{6}{|c|}{$15-30 \mathrm{~cm}$} \\
\hline \multicolumn{2}{|c|}{ Soil samples } & $S_{1}$ & $\mathrm{~S}_{2}$ & $S_{3}$ & $\mathrm{~S}_{4}$ & $\mathrm{~S}_{5}$ & Mean & $S_{1}$ & $\mathrm{~S}_{2}$ & $\mathrm{~S}_{3}$ & $\mathrm{~S}_{4}$ & $\mathrm{~S}_{5}$ & Mean \\
\hline \multicolumn{2}{|c|}{ Site-I (Ganjia) } & 114.70 & 118.23 & 114.20 & 110.00 & 115.23 & 114.47 & 110.36 & 116.76 & 113.20 & 109.23 & 110.26 & 111.96 \\
\hline \multicolumn{2}{|c|}{ Site-II (Arail) } & 99.40 & 98.50 & 96.60 & 95.33 & 93.76 & 96.72 & 98.93 & 97.03 & 95.96 & 94.90 & 93.23 & 96.01 \\
\hline \multicolumn{2}{|c|}{ Site-III (Dandi) } & 95.23 & 94.23 & 93.36 & 92.66 & 91.86 & 93.47 & 94.86 & 93.63 & 93.10 & 92.20 & 91.33 & 93.02 \\
\hline \multicolumn{2}{|c|}{ Mean } & 103.11 & 103.65 & 101.39 & 99.33 & 100.28 & & 101.38 & 102.47 & 100.75 & 98.78 & 98.27 & \\
\hline \multirow[t]{2}{*}{$p<0.05$} & $\begin{array}{c}\text { Soil } \\
\text { samples }\end{array}$ & \multicolumn{6}{|c|}{ NS } & \multicolumn{6}{|c|}{ (a) } \\
\hline & Sites & \multicolumn{6}{|c|}{2.20} & \multicolumn{6}{|c|}{2.35} \\
\hline
\end{tabular}

Table 10. Iron $\left(\mathrm{mg} \mathrm{kg}^{-1}\right)$ in soils of different sites at different depths $(\mathrm{cm})$

\begin{tabular}{|c|c|c|c|c|c|c|c|c|c|c|c|c|c|}
\hline \multicolumn{8}{|c|}{$0-15 \mathrm{~cm}$} & \multicolumn{6}{|c|}{$15-30 \mathrm{~cm}$} \\
\hline \multicolumn{2}{|c|}{ Soil samples } & $S_{1}$ & $\mathrm{~S}_{2}$ & $\mathrm{~S}_{3}$ & $S_{4}$ & $S_{5}$ & Mean & $S_{1}$ & $S_{2}$ & $S_{3}$ & $\mathrm{~S}_{4}$ & $S_{5}$ & Mean \\
\hline \multicolumn{2}{|c|}{ Site-I (Ganjia) } & 98.63 & 95.90 & 96.90 & 97.00 & 96.20 & 96.93 & 97.23 & 96.26 & 96.53 & 96.63 & 95.80 & 96.49 \\
\hline \multicolumn{2}{|c|}{ Site-II (Arail) } & 88.40 & 86.73 & 85.66 & 84.60 & 83.53 & 85.78 & 88.06 & 85.26 & 85.26 & 84.10 & 82.96 & 85.13 \\
\hline \multicolumn{2}{|c|}{ Site-III (Dandi) } & 86.63 & 81.66 & 77.30 & 75.50 & 74.20 & 79.06 & 84.80 & 80.06 & 75.83 & 74.20 & 73.10 & 77.60 \\
\hline \multicolumn{2}{|c|}{ Mean } & 91.22 & 88.10 & 86.62 & 85.70 & 84.64 & & 90.03 & 87.19 & 85.87 & 84.98 & 83.95 & \\
\hline \multirow[t]{2}{*}{$p<0.05$} & $\begin{array}{c}\text { Soil } \\
\text { samples }\end{array}$ & \multicolumn{6}{|c|}{ NS } & \multicolumn{6}{|c|}{ NS } \\
\hline & Sites & \multicolumn{6}{|c|}{3.08} & \multicolumn{6}{|c|}{3.01} \\
\hline
\end{tabular}

The concentration of $\mathrm{Fe}, \mathrm{Mn}$, and $\mathrm{Zn}$ were not affected under short-term wastewater irrigation in the soil. The selected metals maintained the order of $\mathrm{Zn}-\mathrm{Fe}-\mathrm{Mn}$ for wastewater irrigation in the soil in the study area. In the wastewater irrigated soil, $\mathrm{Zn}$ and Fe were found in high concentration, while Mn had low value in comparison with soil irrigated with groundwater. The normal concentration range of these metals in soils is as follows: Fe 30-500 mg kg-1, Mn 300-1000 mg kg-1, and Zn 10-300 mg kg-1 (Blum et al., 2012; Ozturk et al., $2015,2017)$. In the light of these evaluations, Fe and $\mathrm{Zn}$ are found within the permissible ranges, while $\mathrm{Mn}$ is below normal values in the wastewater irrigated soil in the study area.

The mean percentage values for N, P and K recorded in carrot, radish, spinach, cauliflower, and potato showed the highest value in potato and the lowest in carrot. The vegetables grown in Ganjia soils showed the highest content of N, P and K followed by Arail and Dandi. The mean N content of carrot, radish, spinach, cauliflower, and potato was 4.03, 4.43, 4.56, 4.40 and 4.96 percent at Ganjia, 3.16, 3.83, 3.96, 3.73 and 4.13 percent at Arail, and 2.90, 2.53, 3.46, 3.07 and 3.56 percent, respectively at Dandi. Phosphorus content recorded in carrot, radish, spinach, cauliflower and potato was $0.31,0.55,0.73,0.51$ and 0.83 per cent at Ganjia, $0.24,0.40,0.61,0.37$ and 0.67 per cent at Arail, and 0.22, 0.32, 0.51,0.30 and 0.55 per cent, respectively at Dandi. A similar trend was observed with percentage potassium with 3.10, 3.33, 3.80, 3.10 and 4.33 percent recorded at Ganjia, 2.50, 2.70, 3.20, 2.53 and 3.76 percent at Arail, and 2.03, 2.20, 2.70, 2.03 and 3.03 percent at Dandi in carrot, radish, spinach, cauliflower, and potato, respectively (Table 11). 
Haq S et al. (2021). Not Bot Horti Agrobo 49(2):12255

Table 11. Percentage of macronutrient content in the vegetables from different sites

\begin{tabular}{|c|c|c|c|c|c|c|c|}
\hline \multicolumn{8}{|c|}{ Nitrogen } \\
\hline \multicolumn{2}{|l|}{ Sites } & Carrot & Radish & Spinach & Cauliflower & Potato & Mean \\
\hline \multicolumn{2}{|c|}{ Site-I (Ganjia) } & 4.03 & 4.43 & 4.56 & 4.40 & 4.96 & 4.48 \\
\hline \multicolumn{2}{|c|}{ Site-II (Arail) } & 3.16 & 3.83 & 3.96 & 3.73 & 4.13 & 3.76 \\
\hline \multicolumn{2}{|c|}{ Site-III (Dandi) } & 2.90 & 2.53 & 3.46 & 3.07 & 3.56 & 3.10 \\
\hline \multicolumn{2}{|l|}{ Mean } & 3.36 & 3.60 & 3.99 & 3.73 & 4.22 & \\
\hline$p<0.05$ & $\begin{array}{l}\text { Vegetables } \\
\text { sites }\end{array}$ & \multicolumn{6}{|c|}{$\begin{array}{l}0.28 \\
0.28\end{array}$} \\
\hline \multicolumn{8}{|c|}{ Phosphorus } \\
\hline \multicolumn{2}{|c|}{ Site-I (Ganjia) } & 0.31 & 0.55 & 0.73 & 0.51 & 0.83 & 0.59 \\
\hline \multicolumn{2}{|c|}{ Site-II (Arail) } & 0.24 & 0.40 & 0.61 . & 0.37 & 0.67 & 0.46 \\
\hline \multicolumn{2}{|c|}{ Site-III (Dandi) } & 0.22 & 0.32 & 0.51 & 0.30 & 0.55 & 0.38 \\
\hline \multicolumn{2}{|l|}{ Mean } & 0.26 & 0.42 & 0.62 & 0.39 & 0.68 & \\
\hline$p<0.05$ & $\begin{array}{l}\text { Vegetables } \\
\text { sites }\end{array}$ & \multicolumn{6}{|c|}{$\begin{array}{l}0.05 \\
0.05\end{array}$} \\
\hline \multicolumn{8}{|c|}{ Potassium } \\
\hline \multicolumn{2}{|c|}{ Site-I (Ganjia) } & 3.10 & 3.33 & 3.80 & 3.10 & 4.33 & 3.53 \\
\hline \multicolumn{2}{|c|}{ Site-II (Arail) } & 2.50 & 2.70 & 3.20 & 2.53 & 3.76 & 2.94 \\
\hline \multicolumn{2}{|c|}{ Site-III (Dandi) } & 2.03 & 2.20 & 2.70 & 2.03 & 3.03 & 2.40 \\
\hline \multicolumn{2}{|l|}{ Mean } & 2.54 & 2.74 & 3.23 & 2.55 & 3.71 & \\
\hline$p<0.05$ & $\begin{array}{l}\text { Vegetables } \\
\text { sites }\end{array}$ & \multicolumn{6}{|c|}{$\begin{array}{l}0.08 \\
0.08\end{array}$} \\
\hline
\end{tabular}

The normal limits for NPK in the plants are reported to lie in the range of 4-5 percent for N, 0.30-0.70 percent for $\mathrm{P}$, and 3.00-4.50 percent for $\mathrm{K}$ (Jones et al., 1991). An assessment made in terms of $\mathrm{N}$ has revealed that for potatoes the range of values is normal, while in all other vegetables, $\mathrm{N}$ values are below normal. In the case of $\mathrm{P}$, only carrot shows values below the normal level, while all other vegetables are within the normal range. When an assessment for $\mathrm{K}$ is made the values for spinach and potato are at a normal level, but all other vegetables show values below the normal levels.

An overall assessment of our findings points to the fact that this may be due to the fact that soils at Ganjia receive continuous sewage water for irrigation for longer durations and are located next to the sewage discharge point followed Arail and Dandi. As sewage water contains higher amount of N, P, K, and other nutrients, it brings a significant increase in the percentages of N, P, and K in vegetable crops. Similar findings have been reported by Mitra and Gupta (1999), and Reddy et al. (1998).

Sewage waters have significant effect on vegetables like carrot, radish, spinach, cauliflower and potato grown at different sites. The mean values for $\mathrm{Mn}^{2+}\left(\mathrm{mg} \mathrm{kg}^{-1}\right)$ are in the following order; spinach $>$ carrot $>$ radish > cauliflower > potato; for $\mathrm{Zn}^{2+}\left(\mathrm{mg} \mathrm{kg}^{-1}\right)$ as spinach $>$ radish $>$ carrot $>$ potato > cauliflower; and for $\mathrm{Fe}^{2+}\left(\mathrm{mg} \mathrm{kg}^{-1}\right)$ as carrot $>$ spinach $>$ radish $>$ potato $>$ cauliflower in all three sites. The mean $\mathrm{Mn}^{2+}$ content of carrot, radish, spinach, cauliflower and potato was 25.76, 23.70, 32.40, 18.80 and $15.10 \mathrm{mg} \mathrm{kg}^{-1}$ at Ganjia, 18.36, 16.96, 28.26, 12.83 and $13.00 \mathrm{mg} \mathrm{kg}^{-1}$ at Arail, and 11.23, 10.16, 20.43, 9.63 and $8.66 \mathrm{mg} \mathrm{kg}^{-1}$, respectively at Dandi. $\mathrm{Zn}^{2+}$ concentration recorded in carrot, radish, spinach, cauliflower and potato was 249.40, 282.30, 296.80, 179.30 and $170.03 \mathrm{mg} \mathrm{kg}^{-1}$ at Ganjia, 210.76, 230.33, 251.08, 120.30 and $141.33 \mathrm{mg}$ $\mathrm{kg}^{-1}$ at Arail, and 185.33, 200.70, 220.90, 105.70 and $100.13 \mathrm{mg} \mathrm{kg}^{-1}$ at Dandi, respectively. The mean value of 
$\mathrm{Fe}^{2+}$ observed in carrot, radish, spinach, cauliflower and potato was 316.20, 221.03, 213.80, 153.30 and 140.63 $\mathrm{mg} \mathrm{kg}^{-1}$ at Ganjia, 299.36, 180.80, 151.30, 110.46 and $114.70 \mathrm{mg} \mathrm{kg}^{-1}$ at Arail, and 249.90, 110.23, 100.50, 70.30 and $81.20 \mathrm{mg} \mathrm{kg}^{-1}$ at Dandi, respectively (Table 12).

Table 12. Micronutrient content $\left(\mathrm{mg} \mathrm{kg}^{-1}\right)$ in the vegetables cultivated at different sites

\begin{tabular}{|c|c|c|c|c|c|c|c|}
\hline \multicolumn{8}{|c|}{ Manganese } \\
\hline & ites & Carrot & Radish & Spinach & Cauliflower & Potato & Mean \\
\hline \multicolumn{2}{|c|}{ Site-I (Ganjia) } & 25.36 & 23.70 & 32.40 & 18.80 & 15.10 & 23.07 \\
\hline \multicolumn{2}{|c|}{ Site-II (Arail) } & 18.36 & 16.96 & 28.26 & 12.83 & 13.00 & 17.88 \\
\hline \multicolumn{2}{|c|}{ Site-III (Dandi) } & 11.23 & 10.16 & 20.43 & 9.63 & 8.66 & 12.02 \\
\hline \multicolumn{2}{|l|}{ Mean } & 18.32 & 16.94 & 27.03 & 13.75 & 12.25 & \\
\hline$p<0.05$ & $\begin{array}{c}\text { Vegetables } \\
\text { Sites }\end{array}$ & \multicolumn{6}{|c|}{$\begin{array}{l}2.30 \\
2.30\end{array}$} \\
\hline \multicolumn{8}{|c|}{ Zinc } \\
\hline \multicolumn{2}{|c|}{ Site-I (Ganjia) } & 249.90 & 282.30 & 296.80 & 179.30 & 170.03 & 235.67 \\
\hline \multicolumn{2}{|c|}{ Site-II (Arail) } & 210.76 & 230.33 & 251.08 & 120.30 & 141.33 & 190.76 \\
\hline \multicolumn{2}{|c|}{ Site-III (Dandi) } & 185.33 & 200.70 & 220.90 & 105.70 & 100.13 & 162.55 \\
\hline \multicolumn{2}{|l|}{ Mean } & 215.33 & 237.78 & 256.26 & 135.10 & 137.16 & \\
\hline$p<0.05$ & $\begin{array}{l}\text { Vegetables } \\
\text { Sites }\end{array}$ & \multicolumn{6}{|c|}{$\begin{array}{l}8.78 \\
8.78\end{array}$} \\
\hline \multicolumn{8}{|c|}{ Iron } \\
\hline \multicolumn{2}{|c|}{ Site-I (Ganjia) } & 316.20 & 221.03 & 213.80 & 153.30 & 140.63 & 208.99 \\
\hline \multicolumn{2}{|c|}{ Site-II (Arail) } & 299.36 & 180.80 & 151.30 & 110.46 & 114.70 & 171.32 \\
\hline \multicolumn{2}{|c|}{ Site-III (Dandi) } & 249.90 & 110.23 & 100.50 & 70.30 & 81.20 & 102.43 \\
\hline \multicolumn{2}{|l|}{ Mean } & 288.49 & 137.35 & 155.20 & 111.35 & 112.18 & \\
\hline$p<0.05$ & $\begin{array}{l}\text { Vegetables } \\
\text { Sites }\end{array}$ & \multicolumn{6}{|c|}{$\begin{array}{l}17.90 \\
17.90\end{array}$} \\
\hline
\end{tabular}

Generally, crop plants make use of many essential nutrients and trace elements in a short time, therefore, the safety of vegetables is a concern for human health and it has attracted more attention (Khan et al., 2015). Some of the vegetables, such as spinach, radish, and carrot can easily take up heavy metals like copper, cadmium, lead, zinc and manganese in their tissue. Their uptake by plants generally increases when they are grown on contaminated soils (Yang et al., 2011; Khan et al., 2015). The normal limits for manganese and zinc concentrations in plants are reported to lie in the range of $20-400 \mathrm{ppm}$ and $20-100 \mathrm{ppm}$ respectively (Blum et al., 2012). According to Ozturk et al. $(2015,2017)$, the normal limits of iron should be 220-1200 ppm. In the light of these reports, manganese is found within the permissible ranges in spinach, while in all other vegetables the values are below the normal ones in our samples. Iron has been found within the permissible ranges in carrot, but in all other vegetables, the values are below the normal level. The zinc has been found far above the normal values in all vegetables.

The maximum accumulation of $\mathrm{Mn}^{2+}, \mathrm{Zn}^{2+}$, and $\mathrm{Fe}^{2+}$ in vegetables of Ganjia may be due to the fact that it receives continuous sewage water for irrigation and is also located near to the sewage discharge point followed by Arail and Dandi. As sewage water contains a higher amount of micronutrients it brings a significant increase in $\mathrm{Mn}^{2+}, \mathrm{Zn}^{2+}$, and $\mathrm{Fe}^{2+}$ in the vegetables grown. Similar findings have also been reported by Lone et al. (2003), Saraswat et al. (2005), and Gupta et al. (2008). Sewage-amended plants usually result in elevated micronutrient levels, these may accumulate such nutrients to a degree that would be toxic to living beings. Patel et al. (2004) 
have also confirmed that different vegetable crops accumulate invariably high amounts of micronutrients irrespective of the type of effluents/water used for irrigation indicating variable uptake as a function of crop species, cultivar, and selectivity for different elements.

A significant part of the wastewater is already used for crop production in response to the limited availability of fresh water for agriculture by the majority of urban farmers in India, who use wastewater rich in heavy metals like cadmium, chromium, iron, nickel, manganese, lead and zinc (Kumar et al., 2015). In view of this, increasing volumes of wastewater will become the major source of additional irrigation water supplies for farming in water-scarce countries like India (Parashar and Prasad, 2013; Kumar et al., 2015).

\section{Conclusions}

Our studies have revealed that the soils of Ganjia showed the highest value of EC, organic carbon, available NPK, and micronutrients $\left(\mathrm{Mn}^{2+}, \mathrm{Zn}^{2+}\right.$, and $\left.\mathrm{Fe}^{2+}\right)$; whereas, the soils of Dandi contained lower concentrations of available nutrients. The vegetables grown on the soils of Ganjia showed higher NPK content and micronutrients $\left(\mathrm{Mn}^{2+}, \mathrm{Zn}^{2+}\right.$, and $\left.\mathrm{Fe}^{2+}\right)$. Among the vegetables analysed during this study, the potato showed the highest NPK, whereas spinach had higher levels of manganese and zinc. The highest values of iron were recorded in the carrots. In general, the sewage water used for irrigation had a positive impact on nutrient status in soils and vegetable crops. However, it may increase the concentration of toxic metals if used continuously without being subjected to a pre-treatment.

\section{Authors' Contributions}

Conceptualization: $\mathrm{SH}, \mathrm{RB}$ and $\mathrm{RAB}$; Investigation: $\mathrm{SH}, \mathrm{RB}, \mathrm{RAB}, \mathrm{AAB}$ and $\mathrm{MAD}$; Methodology: $\mathrm{SH}, \mathrm{RB}$ and $\mathrm{RAB}$; Formal analysis: $\mathrm{SH}, \mathrm{RB}$ and $\mathrm{RAB}$; Writing-original draft: $\mathrm{SH}, \mathrm{RB}, \mathrm{RAB}, \mathrm{MO}, \mathrm{VA}$ and $\mathrm{KRH}$; and Writing-review and editing: $\mathrm{MO}$ and VA. All authors read and approved the final manuscript.

\section{Acknowledgements}

The authors are grateful to authors/editors/publishers of all those articles, journals and books from where the literature for this article has been reviewed and discussed. In addition, Authors extend sincere thanks to the School of Forestry and Environment, SHIATS, Allahabad, from India; Sher-e-Kashmir University of Agricultural Sciences and Technology, Shalimar, from Kashmir-India; Faculty of Science, King Abdulaziz University, Jeddah from Saudi Arabia; and Hatay Mustafa Kemal University and Ege University in Turkey for their full support in this and ongoing project collaborations.

\section{Conflict of Interests}

The authors declare that there are no conflicts of interest related to this article. 
Haq S et al. (2021). Not Bot Horti Agrobo 49(2):12255

\section{References}

Akınbile CO, Ogunrınde TA, Che BT, Man H, Aziz HA (2016). Phytoremediation of domestic wastewaters in free water surface constructed wetlands using Azolla pinnata. International Journal of Phytoremediation 18:54-61. https://doi.org/10.1080/15226514.2015.1058330

Akhtar S, Iram S, Hassan M, Suther V, Ahmad R (2014). Heavy metal concentration in peri-urban soils and crops under untreated wastewater. International Journal of Scientific \& Engineering Research 5(9):523-535.

Amin N, Hussain A, Alamzeb S, Begüm S (2012). Accumulation of heavy metals in edible parts of vegetables irrigated with waste water and their daily intake to adults and children, District Mardan Pakistan. Food Chemistry 136:1515-1523. https://doi.org/10.1016/j.foodchem.2012.09.058

APHA (1998). Standard methods for the examination of water and wastewater. American Public Health Association, Washington, USA.

Blum WEH, Horak O, Mentler A (2012). Trace elements. In: Sabljic A (Ed). Environmental and Ecological Chemistry. Oxford: UNESCO-EOLSS, pp 156-164.

Chandra R, Bharagava R, Yadav S, Mohan D (2009). Accumulation and distribution of toxic metals in wheat (Triticum aestivum L.) and Indian mustard (Brassica campestris L.) irrigated with distillery and tannery effluents. Journal of Hazardous Materials 162(2-3):1514-1521. https://doi.org/10.1016/j.jhazmat.2008.06.040

Chang CY, Yu HY, Chen JJ, Li FB, Zhang HH, Liu CP (2013). Accumulation of heavy metals in leaf vegetables from agricultural soils and associated potential health risks in the Pearl River Delta, South China. Environmental Monitoring and Assessment 186(3):1547-1560. https://doi.org/10.1007/s10661-013-3472-0

CPCB (2007). Evaluation of operation and maintenance of sewage treatment plants in India-2007. Control of Urban Pollution Series: CUPS/68/2007, Central Pollution Control Board, India.

Farid M, Irshad M, Fawad M, Ali Z, Eneji Ae, Aurangzeb N, ... Ali B (2014). Effect of cyclic phytoremediation with different wetland plants on municipal wastewater. International Journal of Phytoremediation 16:572-581. https://doi.org/10.1080/15226514.2013.798623

FAO/WHO (2011). Joint FAO/WHO food standards programme codex committee on contaminants in foods, Food CF/5 INF/1. Fifth Session. Hague, Netherlands, pp 13-18.

Ghosh AK, Bhatt MA, Agrawal HP (2012). Effect of long-term application of treated sewage water on heavy metal accumulation in vegetables grown in Northern India. Environmental Monitoring and Assessment 184:10251036. https://doi.org/10.1007/s10661-011-2018-6

Gupta N, Khan DK, Santra SC (2008) An assessment of heavy metal contamination in vegetables grown in waste waterirrigated areas of Titagarh, West Bengal, India. Bulletin of Environmental Contamination and Toxicology 80:115-118. https://doi.org/10.1007/s00128-007-9327-z

Iqbal HH, Taseer R, Anwar S (2015). Human health risk assessment: Heavy metal contamination of vegetables in Bahawalpur, Pakistan. Bulletin of Environmental Studies 1(1):10-17.

Jones JB, Wolf B, Mills HA (1991). Plant analysis handbook. Micro-Macro Publishing, USA.

Kashif SR, Akram M, Yaseen M, Ali S (2009). Studies on heavy metals status and their uptake by vegetables in adjoining areas of Hudiara drain in Lahore. Plant Soil and Environment 28(1):7-12.

Kaur R, Wani SP, Singh AK, Lal K (2012). Wastewater production, treatment and use in India. National Report presented at the 2nd regional workshop on Safe Use of Wastewater in Agriculture, India.

Khalid S, Shahid M, Dumat C, Niazi NK, Bibi L, Gul Bakhat HFS, ... Javeed HMR (2017). Influence of groundwater and wastewater irrigation on lead accumulation in soil and vegetables: Implications for health risk assessment and phytoremediation. International Journal of Phytoremediation 19(11):1037-1046. https://doi.org/10.1080/15226514.2017.1319330

Khan A, Javid S, Muhmood A, Majeed T, Niaz A, Mjeed A (2013). Heavy metal status of soil and vegetables grown on peri-urban area of Lahore district. Soil \& Environment 32(1):49-54.

Khan SA, Liu X, Shah BR, Fan W, Li H, Khan SB, Ahmad Z (2015). Metals uptake by wastewater irrigated vegetables and their daily dietary intake in Peshawar, Pakistan. Ecological Chemistry and Engineering 22(1):125-139. https://doi.org/10.1515/eces-2015-0008

Khanum K, Baqar M, Qadir A, Mümtaz M, Tahir A, Jamil A, Mahmood A (2017). Heavy metal toxicity and human health risk surveillances of wastewater irrigated vegetables in Lahore District, Pakistan. Carpathian Journal of Earth and Environmental Sciences 12(2):403-412. 
Kıran DL, Krishna DL, Vivek SM, Ramteke DS (2012). Impact of domestic wastewater irrigation on soil properties and crop yield. International Journal of Scientific and Research Publications 2:1-7.

Kumar V, Chopra AK, Srivastava S, Chauhan RK (2015). Accumulation of heavy metals in vegetables grown in wastewater irrigated soil in Haridwar (Uttarakhand), India. Agricultural Science Research Journal 5(11):146152.

Lone AH, Lal EP, Thakur S, Ganie SA, Wani MS, Khare A, ... Wani FA (2013). Accumulation of heavy metals on soil and vegetable crops grown on sewage and tube well water irrigation. Scientific Research and Essays 8(44):21872193. https://doi.org/10.5897/SRE2013.5636

Lone MI, Saleem S, Khan KS, Mahmood T, Hussain G (2003). Heavy metal contents of vegetables irrigated by sewage/tubewell water in Hassanabadal area. Pakistan Journal of Arid Agriculture 6:65-68.

Mahmood A, Malik RN (2014). Human health risk assessment of heavy metals via consumption of contaminated vegetables collected from different irrigation sources in Lahore, Pakistan. Arabian Journal of Chemistry 7:9199. https://doi.org/10.1016/j.arabjc.2013.07.002

Malla R, Totawat KL (2006). Effect of municipal on soil properties and chemical build-up in vegetable crops grown on Haplustepts of sub-humid Southern plain Rajasthan. Journal of the Indian Society of Soil Science 54:226-231.

Mani D, Sharma B, Kumar C, Balak S (2013). Depth-wise distribution, mobility and naturally occurring glutathione based phytoaccumulation of cadmium and zinc in sewage-irrigated soil profiles. International Journal of Environmental Science and Technology 10(6):1167-1180. https://doi.org/10.1007/s13762-012-0121-z

Maya R, Mhaske AR, Balpande SS, Gawande SN (2016). Impact of food industry effluent on soil and crops of Gumthala Village in Nagpur District. International Journal of Agriculture Sciences 8(52):2500-2503.

Mitra A, Gupta SK (1999) Effect of sewage water irrigation on essential plant nutrient and pollutant element status in a vegetables growing area around Calcutta. Journal of the Indian Society of Soil Science 47:99-105.

Morugan-Coronado A, Garcia-Orenes F, Mataix-Solera J, Arcenegui V, Mataix-Beneyto J (2011). Short-term effects of treated wastewater irrigation on Mediterranean calcareous soil. Soil and Tillage Research 112(1):18-26. https://doi.org/10.1016/j.still.2010.11.004

Murtaza G, Ghafoor A, Qadir M, Owens G, Aziz M, Zia M (2010). Disposal and use of sewage on agricultural lands in Pakistan: A review. Pedosphere 20:23-34. https://doi.org/10.1016/S1002-0160(09)60279-4

Ozturk M, Altay V, Karahan F (2017). Studies on trace elements distributed in Glycyrrhiza taxa in Hatay-Turkey. International Journal of Plant and Environment 3(2):1-7. https://doi.org/10.18811/ijpen.v3i02.10431

Ozturk M, Alyanak I, Sakcali S, Güvensen A (2005). Multipurpose plant systems for renovation of waste waters. The Arabian Journal for Science and Engineering 30(2):17-28.

Ozturk M, Gucel S, Sakcali S, Güvensen A (2011). An overview of the possibilities for wastewater utilization for agriculture in Turkey. Israel Journal of Plant Sciences 59:223-234.

Ozturk M, Ashraf M, Aksoy A, Ahmad MSA, Hakeem KR (2015). Plants, pollutants and remediation. Springer Science + Business Media Dordrecht.

Parashar P, Prasad FM (2013). Study of heavy metal accumulation in sewage irrigated vegetables in different regions of Agra District, India. Open Journal of Soil Science 3:1-8. https://doi.org/10.4236/ojss.2013.31001

Patel KP, Pandya RR, Maliwal GL, Patel KC, Ramani VP, George V (2004) Heavy metal content in different effluents and their relative availability in soil irrigated with effluent water around major industrial cities of Gujarat. Journal of the Indian Society of Soil Science 52:89-94.

Perveen S, Samad A, Nazif W, Shah S (2012). Impact of sewage water on vegetables quality with respect to heavy metals in Peshawar, Pakistan. Pakistan Journal of Botany 44(6):1923-1931.

Pourrut B, Shahid M, Dumat C, Winterton P, Pinelli E (2011). Lead uptake, toxicity, and detoxification in plants. Reviews of Environmental Contamination and Toxicology 213:113-136. https://doi.org/10.1007/978-14419-9860-6_4

Qureshi AS, Hussain ML, İsmail S, Khan QM (2016). Evaluating heavy metal accumulation and potential health risks in vegetables irrigated with treated wastewater. Chemosphere 163:54-61. https://doi.org/10.1016/j.chemosphere.2016.07.073

Randhawa MA, Ahmad G, Anjum FM, Asghar A, Sajid MW (2014). Heavy metal contents and their daily intake in vegetables under peri-urban farming system of Multan, Pakistan. Pakistan Journal of Agricultural Sciences 51(4):1025-1031. 
Rapheal O, Adebayo KS (2011). Assessment of trace heavy metal contaminations of some selected vegetables irrigated with water from river Benue within Makurdi Metropolis, Benue State Nigeria. Advances in Applied Science Research 2:590-601.

Reddy MAN, Ramchandra R, Reddy YTN, Reddy NN, Anjappa M, Reddy R (1998). Effect of organic and inorganic source of N, P, K on growth and yield of pea. Legume Research 21:57-62.

Rojas-Valencia MN, Orta De Velasquez MT, Franco V (2011). Urban agriculture, using sustainable practices that involve the rense of wastewater and solid waste. Agricultural Water Management 98(9):1388-1394. https://doi.org/10.1016/j.agwat.2011.04.005

Saraswat PK, Tiwari RC, Agarwal HP, Sanjay K (2005). Micronutrient status of soils and vegetable crops irrigated with treated sewage water. Journal of the Indian Society of Soil Science 53:111-115.

Shaheen N, Irfan NM, Khan IN, İslam S, İslam H-S, Ahmed MK (2016). Presence of heavy metals in fruits and vegetables: Health risk implications in Bangladesh. Chemosphere 152:431-438. https://doi.org/10.1016/j.chemosphere.2016.02.060

Sharma N, Bhardwaj S, Srivastava PK, Thanki Y, Gadhia P, Gadhia M (2012). Soil chemical changes resulting from irrigating with petrochemical effluents. International Journal of Environmental Science and Technology 9:361370. https://doi.org/10.1007/s13762-012-0039-5

Singh A, Sharma RK, Agarwal M, Marshall FM (2010). Risk assessment of heavy metal toxicity through contaminated vegetables from waste water irrigated area of Varanasi, India. Tropical Ecology 51(2):375-387.

Singh RS, Singh RR (1994). Differential toxicity of heavy metals to growth and nitrate reductase activities of Sesaniun indicum seedlings. Phytochemistry 35:1153-1156. https://doi.org/10.1016/S0031-9422(00)94812-X

Singh S, Kumar M (2006). Heavy metal load of soil, water and vegetables in peri-urban Delhi. Environmental Monitoring and Assessment 120(1-3):79-91. https://doi.org/10.1007/s10661-005-9050-3

Singh SP, Verloo MG (1996). Accumulation of bioavailability of metals in semi-arid soils irrigated with sewage effluent. Mededelingen FLTBW 60:63-67.

Tiwari KK, Singh NK, Patel MP, Tiwari MP, Rai UN (2011). Metal contamination of soil and translocation in vegetables growing under industrial wastewater irrigated agricultural field of Vadodara, Gujarat, India. Ecotoxicology and Environmental Safety 74(6):1670-1677. https://doi.org/10.1016/j.ecoenv.2011.04.029

Verma P, Agrawal M, Sağar R (2015). Assessment of potential health risks due to heavy metals through vegetable consumption in a tropical area irrigated by treated wastewater. Environment Systems and Decisions 35(3):375388. https://doi.org/10.1007/s10669-015-9558-1

Wantong SI, Liu J, Cai L, Jiang H, Zheng C, He X, Zhang X (2014). Health risks of metals in contaminated farmland soils and spring wheat irrigated with Yellow River water in Baotou, China. Bulletin of Environmental Contamination and Toxicology 94(2):214-219. https://doi.org/10.1007/s00128-014-1435-y

WWF (World Wide Fund for Nature) (2007). National surface water classification criteria and irrigation water quality guidelines for Pakistan. Hudiara Drain Project Phase II, funded by UNDP under GEF small grants programme. World Wide Fund for Nature, Lahore, Pakistan, pp 12-26.

Xiong T, Dumat C, Pierart A, Shahid M, Kang Y, Li N, ... Laplanche C (2016). Measurement of metal bio accessibility in vegetables to improve human exposure assessments: field study of soil-plant-atmosphere transfers in urban areas, South China. Environmental Geochemistry and Health 38:1283-1301. https://doi.org/10.1007/s10653-0169796-2

Xue ZJ, Liu SQ, Liu YL, Yan YL (2012). Health risk assessment of heavy metals for edible parts of vegetables grown in sewage irrigated soils in suburbs of Baoding City, China. Environmental Monitoring and Assessment 184:35033513. https://doi.org/10.1007/s10661-011-2204-6

Yadav RK, Goyal B, Sharma RK, Dubey SK, Minhas PS (2002). Post irrigation impact of domestic sewage effluent on composition of soils, crops grown there upon and ground water - A case study. Environment International 28:481-486. https://doi.org/10.1016/S0160-4120(02)00070-3

Yang Q, Xu Y, Liu S, He J, Long F (2011). Concentration and potential health risk of heavy metals in market vegetables in Chongqing, China. Ecotoxicology and Environmental Safety 74:1664-1669. https://doi.org/10.1016/j.ecoenv.2011.05.006

Zia MH, Watts MJ, Niaz A, Middleton DR, Kim AE (2016). Health risk assessment of potentially harmful elements and dietary minerals from vegetables irrigated with untreated wastewater, Pakistan. Environmental Geochemistry and Health 39(4):707-728. https://doi.org/10.1007/s10653-016-9841-1 
OPEN ACCESS

(c) (2)

The journal offers free, immediate, and unrestricted access to peer-reviewed research and scholarly work. Users are allowed to read, download, copy, distribute, print, search, or link to the full texts of the articles, or use them for any other lawful purpose, without asking prior permission from the publisher or the author.

License - Articles published in Notulae Botanicae Horti Agrobotanici Cluj-Napoca are Open-Access, distributed under the terms and conditions of the Creative Commons Attribution (CC BY 4.0) License. (C) Articles by the authors; UASVM, Cluj-Napoca, Romania. The journal allows the author(s) to hold the copyright/to retain publishing rights without restriction. 